\title{
Coinfection with SARS-CoV-2 and influenza A virus
}

\author{
Yuki Kondo, Shinichi Miyazaki () , Ryo Yamashita, Takuya Ikeda
}

Department of Respiratory Medicine, Yokkaichi Municipal Hospital, Yokkaichi, Mie, Japan

\section{Correspondence to} Dr Shinichi Miyazaki; miyazaki.sin1@gmail.com

Accepted 23 June 2020

Check for updates

(C) BMJ Publishing Group Limited 2020. No commercial re-use. See rights and permissions. Published by BMJ.

To cite: Kondo Y, Miyazaki S, Yamashita $\mathrm{R}$, et al. BMJ Case Rep 2020;13:e236812. doi:10.1136/bcr-2020236812

\section{SUMMARY}

Since December 2019, coronavirus disease 2019 (COVID-19) has been an international public health emergency. The possibility of COVID-19 should be considered primarily in patients with new-onset fever or respiratory tract symptoms. However, these symptoms can occur with other viral respiratory illnesses. We reported a case of severe acute respiratory syndrome coronavirus 2 and influenza A virus coinfection. During the epidemic, the possibility of COVID-19 should be considered regardless of positive findings for other pathogens.

\section{BACKGROUND}

In late 2019, a novel coronavirus, known as severe acute respiratory syndrome coronavirus 2 (SARS-CoV-2), was identified as the cause of an outbreak of acute respiratory illness in Wuhan, China. Since then, there has been a rapid spread of the virus, leading to a global pandemic of coronavirus disease 2019 (COVID-19). We report a case of coinfection with SARS-CoV-2 and influenza A virus in a patient with pneumonia in Japan. The patient with both COVID-19 and influenza virus infection presented similar clinical characteristics with COVID-19 only. During the epidemic, the possibility of COVID-19 should be considered regardless of positive findings for other pathogens.

\section{CASE PRESENTATION}

In April 2020, a 57-year-old Japanese man was admitted to our hospital with an 8-day history of fever and non-productive cough. Six days before admission, the patient presented first to general practitioners. The patient had a positive result for influenza A from a nasopharyngeal swab test. The patient was prescribed with laninamivir, but his symptoms did not improve. Two days before admission, the patient was referred to our hospital for a prolonged fever. Anteroposterior chest radiograph (figure 1A) found ground-glass opacities (GGO) in the left lung and he was treated with garenoxacin. Later, real-time reverse transcription-polymerase chain reaction (rRT-PCR) of his nasopharyngeal swab returned positive for SARS-CoV-2. His medical history included vasospastic angina and diabetes mellitus. His medications were sitagliptin and miglitol. He worked as customer service in a restaurant. There was no history of smoking, travel or any contact with sick people.

On admission, the patient reported of shortness of breath, anosmia and ageusia. Vital signs were as follows: temperature, $38.8^{\circ} \mathrm{C}$; blood pressure
131/74, mm Hg; heart rate, 80 beats/min; respiratory rate, 20 breaths/min; and oxygen saturation, $91 \%$ on room air with desaturation on minimal exertion.

\section{INVESTIGATIONS}

Complete blood count revealed white blood cells, $8.3 \times 10^{9} / \mathrm{L}$ (neutrophils, 86\%; lymphocytes, $8 \%$; and monocytes, 6\%); haemoglobin $144 \mathrm{~g} / \mathrm{L}$; mean corpuscular volume, $96 \mathrm{fL}$; and platelets, $199 \times 10^{9} /$ L. Serum laboratory test results were as follows: total protein, $6.5 \mathrm{~g} / \mathrm{dL}$; albumin, $3.1 \mathrm{~g} / \mathrm{dL}$; total bilirubin, $0.6 \mathrm{mg} / \mathrm{dL}$; aspartate aminotransferase, $103 \mathrm{IU} / \mathrm{L}$; alanine transaminase, $161 \mathrm{IU} / \mathrm{L}$; g-glutamyl transferase, $114 \mathrm{IU} / \mathrm{L}$; lactate dehydrogenase, $416 \mathrm{IU} / \mathrm{L}$; blood urea nitrogen, $11 \mathrm{mg} / \mathrm{dL}$; creatinine, $0.8 \mathrm{mg} / \mathrm{dL}$; sodium, $136 \mathrm{mmol} / \mathrm{L}$; potassium, $4.6 \mathrm{mmol} / \mathrm{L}$; chloride, $97 \mathrm{mmol} / \mathrm{L}$; glucose, $231 \mathrm{mg} / \mathrm{dL}$; haemoglobin A1c, 7.2\%; ferritin, 1695 $\mathrm{ng} / \mathrm{mL}$; C-reactive protein, $15.7 \mathrm{mg} / \mathrm{dL}$; and procalcitonin, $<0.1 \mathrm{ng} / \mathrm{mL}$. Hepatitis B surface antigen and anti-hepatitis $C$ virus were negative. An ECG was normal. Anteroposterior chest radiography (figure $1 \mathrm{~B}$ ) revealed consolidation in the left lung. Further evaluation with CT scanning of the chest (figure 2) found peripheral, bilateral, GGO with consolidation and visible intralobular lines (crazypaving appearance). Sputum cultures for bacteria, fungus and acid-fast bacilli were all negative.

\section{DIFFERENTIAL DIAGNOSIS}

Initial considerations for this patient who presented acutely with fever and cough include infection with a common virus (rhinoviruses, non-SARS-CoV-2 coronaviruses and influenza virus) and communityacquired pneumonia. The rapid antigen testing and his clinical course make influenza pneumonia likely. Owing to the SARS-CoV-2 outbreak in Japan, COVID-19 also needs to be considered.

\section{TREATMENT}

Ciclesonide inhaler $(200 \mu \mathrm{g}$ two times per day for 14 days), favipiravir (1800 mg two times per day at day 1 , followed by $800 \mathrm{mg}$ two times per day for a total duration of 14 days) and broad-spectrum antibiotics (meropenem and azithromycin) were initiated.

\section{OUTCOME AND FOLLOW-UP}

Soon after hospitalisation, the patient developed progressive hypoxaemia (oxygen saturation of $91 \%$ on $2 \mathrm{~L} / \mathrm{min}$ via nasal cannula). The fever continued for the first 4 days of hospitalisation, but subsequently abated. At day 7 of hospitalisation, the 


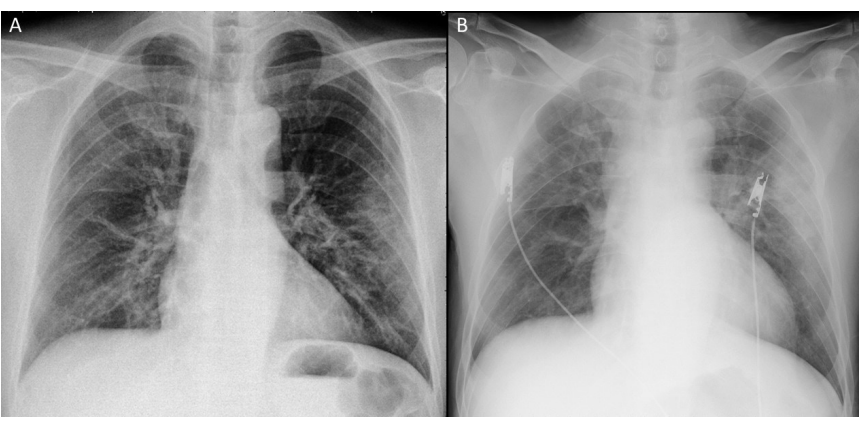

Figure 1 Chest radiograph 2 days before admission $(A)$ and on admission (B).

patient's dyspnoea and hypoxaemia improved. According to discharge criteria for confirmed COVID-19 cases in Japan (2 negative rRT-PCR tests from nasopharyngeal swabs at 24 hours interval and clinical improvement of signs and symptoms), he was discharged home 4 weeks after hospitalisation. Fortunately, because of the small number of patients with COVID-19 in our area, the patient was placed in a single-patient, negative-pressure room. All healthcare workers who enter the room of the patient wore personal protective equipment.

\section{DISCUSSION}

Coinfection with SARS-CoV-2 and other respiratory viruses has been described, but the reported frequency is variable. Among 5700 patients hospitalised with COVID-19 in New York City, 42 patients $(2.1 \%)$ had respiratory virus coinfection with enterovirus/rhinovirus (22/42), other coronavirus (7/42), respiratory syncytial virus (4/42), parainfluenza 3 (3/42), human metapneumovirus (2/42) and influenza A virus (1/42). ${ }^{1}$ In Northern California, the coinfection rate between SARS-CoV-2 and other respiratory pathogens was $20.7 \%$. $^{2}$ The coinfections were enterovirus/rhinovirus (6.9\%), respiratory syncytial virus (5.2\%), other Coronaviridae (4.3\%), human metapneumovirus $(1.7 \%)$ and influenza A virus (0.9\%). There was no significant difference in the rates of SARS-CoV-2 infection in patients with and without other pathogens. The presence of a non-SARS-CoV-2 pathogen may not provide reassurance that a patient does not also have SARS-CoV-2. In Wuhan, China, 5 of 115 patients (4.35\%) confirmed with COVID-19 were diagnosed with influenza virus infection, with 3 cases being of influenza $A$ and 2 cases of influenza B. ${ }^{3}$ The clinical characteristics of patients with both COVID-19 and influenza virus infection were similar to those of COVID-19 cases.

Now, the National Institutes of Health COVID-19 treatment guidelines recommend remdesivir for hospitalised patients with severe COVID-19. ${ }^{4}$ However, at that time, no drug had been

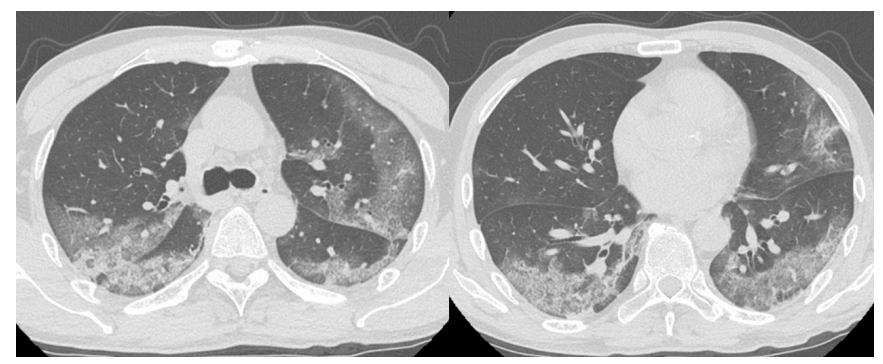

Figure 2 Chest CT on admission. proven to be safe and effective for treating COVID-19. Therefore, with the consent of the patient, off-label use of ciclesonide and favipiravir was administered. In vitro studies have demonstrated that ciclesonide has good antiviral activity against SARS-CoV-2. ${ }^{5}$ Although the clinical effectiveness of ciclesonide in the treatment of COVID-19 was reported in some cases, ${ }^{6}$ there is no clinical trial to evaluate its antiviral activity in patients with COVID-19. Favipiravir is an RNA polymerase inhibitor that is available in some Asian countries for the treatment of influenza. In an openlabel non-randomised control study, favipiravir was compared with lopinavir/ritonavir for the treatment of non-severe COVID$19 .^{7}$ A shorter viral clearance time was found for favipiravir than lopinavir/ritonavir (median, 4 vs 11 days, $\mathrm{p}<0.001$ ). At day 14 after treatment, the improvement rates on chest CT with favipiravir were significantly higher than lopinavir/ritonavir $(91.4 \%$ vs $62.2 \%, p=0.004)$. These data support further investigation with randomised clinical trials on the efficacy of favipiravir for the treatment of COVID-19.

\section{Learning points}

- There was no significant difference in rates of severe acute respiratory syndrome coronavirus 2 (SARS-CoV-2) infection in patients with and without other pathogens.

- SARS-CoV-2 mimics the clinical characteristics of the influenza virus.

- During the epidemic, the possibility of COVID-19 should be considered regardless of positive findings for other pathogens.

Contributors YK and SM wrote the initial manuscript and edited it. RY and TI supervised and edited the manuscript to its completion. All authors read and approved the final version of the manuscript.

Funding The authors have not declared a specific grant for this research from any funding agency in the public, commercial or not-for-profit sectors.

Competing interests None declared.

Patient consent for publication Obtained.

Provenance and peer review Not commissioned; externally peer reviewed.

This article is made freely available for use in accordance with BMJ's website terms and conditions for the duration of the covid-19 pandemic or until otherwise determined by BMJ. You may use, download and print the article for any lawful, non-commercial purpose (including text and data mining) provided that all copyright notices and trade marks are retained.

\section{ORCID iD}

Shinichi Miyazaki http://orcid.org/0000-0002-6700-7675

\section{REFERENCES}

1 Richardson S, Hirsch JS, Narasimhan M, et al. Presenting characteristics, comorbidities, and outcomes among 5700 patients hospitalized with COVID-19 in the new York City area. JAMA 2020. doi:10.1001/jama.2020.6775. [Epub ahead of print: 22 Apr 2020].

2 Kim D, Quinn J, Pinsky B, et al. Rates of co-infection between SARS-CoV-2 and other respiratory pathogens. JAMA 2020. doi:10.1001/jama.2020.6266. [Epub ahead of print: 15 Apr 2020].

3 Ding Q, Lu P, Fan Y, et al. The clinical characteristics of pneumonia patients coinfected with 2019 novel coronavirus and influenza virus in Wuhan, China. J Med Virol 2020;382. doi:10.1002/jmv.25781. [Epub ahead of print: 20 Mar 2020].

4 National Institutes of health (NIH). coronavirus disease 2019 (COVID-19) treatment guidelines. NIH 2020

5 Jeon $\mathrm{S}$, Ko M, Lee J, et al. Identification of antiviral drug candidates against SARS-CoV-2 from FDA-approved drugs. Antimicrob Agents Chemother 2020;64 doi:10.1128/AAC.00819-20. [Epub ahead of print: 04 May 2020].

6 Iwabuchi K, Yoshie K, Kurakami Y, et al. Therapeutic potential of ciclesonide inahalation for COVID-19 pneumonia: report of three cases. J Infect Chemother 2020;26:625-32.

7 Cai Q, Yang M, Liu D, et al. Experimental treatment with Favipiravir for COVID-19: an open-label control study. Engineering 2020. doi:10.1016/j.eng.2020.03.007. [Epub ahead of print: 18 Mar 2020]. 
Copyright 2020 BMJ Publishing Group. All rights reserved. For permission to reuse any of this content visit https://www.bmj.com/company/products-services/rights-and-licensing/permissions/

BMJ Case Report Fellows may re-use this article for personal use and teaching without any further permission.

Become a Fellow of BMJ Case Reports today and you can:

- Submit as many cases as you like

Enjoy fast sympathetic peer review and rapid publication of accepted articles

Access all the published articles

Re-use any of the published material for personal use and teaching without further permission

Customer Service

If you have any further queries about your subscription, please contact our customer services team on +44 (0) 2071111105 or via email at support@bmj.com.

Visit casereports.bmj.com for more articles like this and to become a Fellow 